\title{
Learning from participants' responses in educational drama in the teaching of Education for Sustainable Development
}

\author{
Marie Jeanne McNaughton * \\ University of Strathclyde, Glasgow, Scotland, UK
}

\begin{abstract}
The context for this paper is an on-going research project that sets out to examine the use of educational drama in the teaching of Education for Sustainable Development (ESD) in the upper stages of primary school. The drama lessons link with some of the key aims in ESD, with a particular locus in the Scottish education system. As 2005-15 has been designated by UNESCO as 'The Decade of Education for Sustainable Development', it is particularly important to examine and emphasise the key role of drama in the learning process. The main focus of the paper is the examination of what pupils' evaluations of the drama work reveal about how drama might be particularly appropriate for use in ESD-related work. The relationships between the participants in the drama, teacher and pupils, both in and out of role are explored. The conclusions suggest that active, participative learning and the unique way of working within the dramatic context might allow children to develop skills and attitudes necessary for active citizenship and might facilitate learning in ESD.
\end{abstract}

\section{The location of the research}

\section{Education for Sustainable Development}

The 1992 Earth Summit in Rio (United Nations Conference on the Environment and Development-UNCED) emphasised the central role of education in helping young people to understand world problems and to equip them with the skills and attitudes needed to take action to alleviate them. The Johannesburg Summit ten years later acknowledged that things had moved only slowly. Since then, there has been a more concerted effort in the UK and worldwide to increase the focus of attention on the environment and on Sustainable Development education. Global and local issues such as depletion of the earth's resources, the consequences of global warming, social inequality, poverty and starvation, and growth in the world's population continue to be in the news and are increasingly a focus for politicians rather than being seen as the concern of 'fringe' protest groups. Those working in the

^Department of Childhood and Primary Studies, University of Strathclyde, Sir Henry Wood Building, Jordanhill Campus, 76 South Brae Drive, Glasgow G13 1PP, Scotland, UK. Email: m.j.mcnaughton@strathclyde.ac.uk 
education sector are increasingly aware of the need to develop frameworks through which these issues can be addressed.

In 2004 Learning and Teaching Scotland published a research study that documented the development of the provision for Education for Sustainable Development in the UK since 1992 (Sustainable Development Education Liaison Group, 2004). As well as outlining the range of current provision, some key recommendations were made for development of ESD within the curriculum. Among these were that: ESD should be more closely linked to citizenship education (going beyond civic skills to looking at global citizenship); personal and social education should involve ESD; and that a more cross-curricular, thematic approach should be adopted in ESD.

Education for Citizenship in Scotland (LT Scotland, 2002) outlines examples of learning for (global) citizenship, in terms of knowledge and understanding, skills and competencies, values and dispositions, and creativity and enterprise (pp. 11-14). Pupils should appreciate the need to base opinions, views and decisions on relevant knowledge and on a critical evaluation and balanced interpretation of evidence, and should be aware of the complexity of the economic, ethical and social issues and dilemmas that confront people. Core skills are described as those widely recognised as also being essential for personally rewarding living, while 'competence' is used to describe generic skills and personal qualities such as self-esteem, confidence, initiative, determination and emotional maturity needed in order to be responsible and effective participants in a community. Pupils should be encouraged to develop the ability to recognise and respond thoughtfully to values and value judgements that are part of political, economic, social and cultural life and to respect and care for self, for others and for the environment. Creative and enterprising citizenship involves making thoughtful and imaginative responses to issues and problems in local, national and global communities. I consider that many of these areas of learning may be approached through drama.

UNESCO has designated 2005-15 as 'The Decade of Education for Sustainable Development'. The stated vision for ESD is 'a world where everyone has the opportunity to benefit from quality education and learn the values, behaviour and lifestyles required for a sustainable future and for positive societal transformation' (UNESCO website, 2005).

UNESCO (2005) describes the key qualities and features in ESD. These include:

1. interdisciplinary and holistic: learning for sustainable development embedded in the whole curriculum, not as a separate subject;

2. values-driven: it is critical that the assumed norms - the shared values and principles underpinning sustainable development-are made explicit so that they can be examined, debated, tested and applied;

3. critical thinking and problem solving: leading to confidence in addressing the dilemmas and challenges of sustainable development; 
4. multi-method: word, art, drama, debate, experience, ... different pedagogies which model the processes. There should be creative ways of expressing new concepts;

5. participatory decision-making: learners participate in decisions on how they are to learn.

The links with drama education, specifically mentioned in point 4, 'multimethod' are evident. Many of the features described in this list have been attributed to learning in drama by writers and researchers in the field of drama education.

\section{The role of educational drama}

Edmund et al. (2001) state that drama (in this case role-play based on a play, 'Woven Lives' by Amanda Wild about life in Guatemala) 'encourages us to explore and empathise with the lives of people in different places and situations' (p. 3). The drama used in this research is not based on pre-written scripts or on performance. Rather, it is based on the theories and techniques of international practitionerresearchers such as Dorothy Heathcote (in Wagner, 1976), Gavin Bolton (1984), Patrice Baldwin (2004), and Jonothan Neelands (1990, 1992). 'Drama in Education' (Bolton, 1984) or 'Process Drama' (O’Neill, 1995) is non-performance based, improvised and often employs the strategy of teacher-in-role. It is concerned with exploring ideas and feelings and looking at different perspectives. Working in role, both teacher and pupils are actively recreating and adapting their perceptions of the world and the people in it. Out of role, reflection and analysis of the drama helps to extend and deepen understanding of how human beings respond and react to experiences and situations. Although educational drama employs many of the techniques of theatre and acknowledges drama as an art form, unlike theatre, there is often no external audience for the work. In the process of participating in the drama, and during the reflection and evaluation, the participants 'live through' the drama rather than watching from the outside.

It is my hypothesis that educational drama might be able to help in the exploration of specific sustainability and global education ideas and issues, and in the development of the communication, collaboration and decision-making skills necessary for learning in ESD. It might also help to increase the pupils' appreciation of and sensitivity to others and to local and global environmental issues. Positive findings might encourage a broader, more integrated approach to this area of the curriculum. McNaughton (2004) found that the areas where drama might be particularly useful in Education for Sustainability were in engendering sympathy and empathy, in developing a range of skills such as communication and collaboration, in exploring values, and in providing a meaningful context for research about environmental issues. These ideas will be developed further in the course of this article. 


\section{The research questions}

Specifically, this inquiry sought to find out which specific ESD learning outcomes, for example, in concepts, skills, values, positive attitudes, sympathy/ empathy with others, may be addressed through the medium of drama. In addition, it wished to examine the drama techniques and conventions that might be employed in order to help children to explore issues and to extend their learning in ESD. Data in the form of field notes, evaluations, interviews, observation schedules and videotapes of lessons were gathered over a period of approximately one school year and were sorted, categorised and subjected to a range of analysis in the period thereafter.

\section{Methodology}

Central to the inquiry was a small-scale qualitative research study in three phases (initially two, but later extended). In Phase 1, I planned and taught two sets of drama lessons based on sustainability and citizenship themes, one local and one global theme. Each set of lessons was to be implemented with two classes of Primary 7 (Year 6) children, Classes A and B, from two different schools. Strategies were planned for the collection of data and its subsequent analysis. In Phase 2, the lessons were to be replicated by a teacher from a different, third school with her class-Class C. By asking another teacher to independently teach and evaluate the lessons, I hoped to provide triangulation and reduce the possibilities of bias in later analysis of the children's learning (Bell, 1993). Phase 3 took place some time after the initial two phases were completed. This involved follow-up work carried out by me in two further schools where hypotheses could be further explored and tested.

\section{The approach}

The main method used in the research was case study. In this work there was a multicase approach as the processes (i.e. the drama and ESD process) and the episodes (i.e. the sets of lessons) were repeated on a number of occasions using different subjects. This approach has a 'rolling' quality, with the on-going observation and analysis process enabling the researcher to obtain feedback that could be fed into the next piece of work. Therefore, although the same lessons were repeated with each of the sample classes, the objective of the research was not solely to seek replication of the outcomes. Rather, it was hoped that, by referring to and learning from earlier lessons, an accumulation of knowledge about the effects of the drama would be gained. This feature, along with participant observation, the focus on descriptive data and the holistic perspective, places this study within the scope of Action Research (Stenhouse, 1975). 


\section{The sample}

I recognise that both the internal and external validity of the research will be dependent upon the decisions that are made about the scope of the lessons and the selection of the sample (Hitchcock \& Hughes, 1995). When selecting the sample classes for my teaching I considered a number of factors, for example, the willingness of the teachers to participate by completing observation schedules and engaging in the follow-up class tasks. I also had to consider the age and stage of the children. By careful planning of the materials, by giving clear instructions to observers and by teaching the lessons myself, I hoped to minimise the external variables.

\section{The lessons}

Since the introduction of the 5-14 National Curriculum Guidelines in Scotland in 1987-91, there has been a tendency for the curriculum in primary schools to become fragmented and compartmentalised with a focus on subject knowledge and skills. While there is a clear edict to ensure progression and balance, the advice contained within the documents also makes clear that 'learning activities should interrelate wherever this can help make them more comprehensive, coherent and relevant to the pupils ...' (SOED, 1991, p. 11). This lack of integration is a focus in the revised curriculum consultation document, A Curriculum for Excellence (Scottish Office Curriculum Review Group, 2004). It states that, 'children's learning activities should combine to form a coherent experience. There should be clear links between the different aspects of young people's learning, including opportunities for extended activities which draw different strands of learning together' (p. 18). It was vital that the drama took place within the context of wider classroom topics in ESD rather than being stand-alone lessons. The topics integrated a number of curricular areas including geography, art, maths, talking and listening, and personal and social development. Although specific skills and techniques in drama would be introduced and developed, the key learning purpose was to enhance and extend the children's learning in the topic through the medium of drama.

The first set of lessons, which took place as part of a class topic on 'Waste and Recycling', looked at a local issue-illegal dumping of rubbish and waste or 'flytipping' - and the effects that this had on a small community. The residents (children in role) living across from the dumping site experienced increasing levels of discomfort. They appealed for help to the local council (teacher in role) but with limited success. Eventually, they made plans and took action to deal with the problem themselves. The third set of lessons, which took place after the initial data collection and analysis from Phases 1 and 2 was completed, focused on a Personal and Social Development/ESD topic, 'Rules for Living Together', where issues of social justice and human rights were explored in the context of a community starting a new society (after a group of refugees had been shipwrecked).

This article deals with the second set of lessons. These looked at a global issue, a topic based on the destruction of the rainforests, looking at the reasons for 
deforestation and the effects of this on the environment. It was decided, with the class teachers, that the drama should focus on communities who live in and depend on the forests and to explore a range of perspectives on the issues surrounding deforestation. A key theme for the drama was 'dispossession'. The drama viewed the issue mainly from the perspective of a group of villagers (children in role) whose homes were threatened by deforestation, although in part of the drama the children switched roles to become the loggers who were working in the forest. Dramatic encounters occurred between the villagers and a messenger from another community who had come with news of the approaching deforestation, villagers and loggers, and villagers and a representative from the forest and her aids from the clearing company whose job it was to remove the villagers to another location. Various meetings took place and finally the villagers had to decide whether or not to leave the forest voluntarily. The lessons were planned to explore the feelings and responses of people whose way of life is being threatened and to consider the human cost of global expansion and development.

The planning for this work threw up a particular concern. There was an awareness of the need not to present the rainforest people in a way that would create or reinforce the stereotype of a 'backward' or 'quaint' society. Steps were taken to try to prevent this. After the initial planning, I took the lessons to a group of international students, sponsored by WWF, who were studying for a Certificate in Environmental Education at the University of Strathclyde. These students came from a number of developing world countries in Asia, Africa and South America. A useful discussion both alerted me to possible areas of concern and reassured me of the basic soundness of the content and methodology. Several members of the group told stories of their families being displaced or relocated because of development and, indeed, the character and behaviour of the clearing company representative was based on one student's description of his father's experience. It was decided to set the story about 20 years in the past and to present it as a fictional-historical account rather than a representation of the current position. This enabled the community to have had less contact with the developed world and to be less influenced by current globalisation. It was also decided not to set the story in any specific geographical location. The theme of dispossession was not location-dependent and I did not want the central issues to focus on any one country or people. De-briefing and discussion following each of the lessons allowed any basic misconceptions to be addressed and key areas of learning to be reinforced. Finally, as the drama was part of an on-going 'Rainforest' topic, it was essential that, as part of their class-based (and home-based) research and study, the children learned some key facts relating to the topography and ecology of the rainforests and to the lifestyles of past and present forest dwellers.

Laing and McNaughton (2001) propose an 'action competence' model of learning in environmental education (p. 173). They suggest that teachers plan activities to give children opportunities to work in ways that develop their knowledge and insights about the environment, their commitment to and vision of the environment and their ability to take positive action for the environment. Activities linked to the drama lessons included undertaking group research about the rainforest, writing individual 
and group poems on rainforest themes, writing speech bubbles giving different perspectives (views of different villagers, loggers and developers) on the situations explored within the drama, and making posters for school and home describing the effects of deforestation and advising readers of alternatives to, for example, buying hardwood items from unsustainable sources. Initial assessment of learning from these tasks was undertaken by examining the range of pupils' responses both within and outwith the drama in conjunction with lists of proposed learning outcomes. Table 1 shows the range of 'Aims and Learning Outcomes' proposed for 'The Rainforest' drama lessons. These are linked to key Knowledge and Concepts, Skills and Attitudes in EDS. They also fit with the learning outcomes described in Education for Citizenship in Scotland (LT Scotland, 2002), previously outlined. The codes used in the analysis of the responses of the children are also shown.

\section{The data}

The undertaking of the teaching and data gathering for Phase 1 was carried out over a period of 12 weeks - approximately one school term. I worked for one half day each week in each of the two classes, Class A and Class B. During this period, I also undertook interviews with the pupils and teachers and collected other relevant data. As I taught the lessons to the classes, the class teachers observed and completed the observation schedules. After each lesson, I talked to the teacher briefly, answering questions or clarifying points. On-going field notes were written after each session in school.

By the end of Phase 1 of the project I had gathered a considerable and diverse range of sources of data. These included written and drawn responses, written evaluations, recordings of interviews with groups of children and teachers, teachers' observation notes, my field notes in my research diary and videotapes of my lessons.

\section{Analysis of the data}

Having accumulated, sorted and transcribed a wide range of data, the next step was to try to make some sense of them. I wanted to find out what the raw data were telling me and to attempt to use them to give me answers to the questions posed at the beginning of the study. Initially, I was looking for evidence of learning and for comments which might give insights into any aspect of the teaching and learning process. The decisions about how to proceed were dictated, to some extent, by the nature of the research questions themselves.

\section{Stages in analysis}

Evidence of learning in environmental education could be found, in the first instance, by scrutinising the children's written and oral responses, and the observers' comments for indications that the proposed learning outcomes had been met. Each 
Table 1. Proposed ESD. Learning linked to aims and learning outcomes and codes for the analysis of the children's responses to 'The Rainforest'

\begin{tabular}{|c|c|c|}
\hline Aims and Learning Outcomes & ESD Concepts and Knowledge & Codes \\
\hline $\begin{array}{l}\text { Aim } 1 \\
\text { To raise the children's awareness } \\
\text { of the situation faced by people affected } \\
\text { by the destruction of the rainforests } \\
\text { Learning Outcome } 1 \\
\text { The children will be able to } \\
\text { describe the lives of the community } \\
\text { in the forest and compare to } \\
\text { their own lifestyle } \\
\text { Learning Outcome } 2 \\
\text { The children will be able to identify } \\
\text { how people can take action for }\end{array}$ & $\begin{array}{l}\text { - The lifestyle of people who } \\
\text { live in a rainforest } \\
\text { - Problems of rainforest } \\
\text { dwellers if the forest was } \\
\text { being destroyed } \\
\text { - Consequences for } \\
\text { rainforest dwellers of } \\
\text { moving out of the forest } \\
\text { - Actions that can be taken } \\
\text { to decrease the extent of } \\
\text { deforestation }\end{array}$ & $\begin{array}{ll}\text { - } & \mathrm{CK} 1 \\
\text { - } & \mathrm{CK} 2 \\
\text { - } & \mathrm{CK} 3 \\
\text { - } & \mathrm{CK} 4\end{array}$ \\
\hline
\end{tabular}

the protection of the rainforests

Aim 2

To develop a drama/narrative that allows the children to respond to the issues surrounding deforestation-social, environmental and economic - from the perspective of the people of the forest

Learning Outcome 3

The children will be able to express views and take a stance on the issue of deforestation within the context of the 'Rainforest' drama

Aim 3

To encourage the children to adopt positive attitudes towards the environment and to express a personal view on the issues of deforestation and displacement

\section{Learning Outcome 4}

The children will be able to identify and describe the villagers'

thoughts and feelings about eviction

\section{ESD Skills}

- Using information and imagination to devise/ develop a character

- $\mathrm{S} 1$

- S2

- S3

- Collaborating (working - S4 together, sharing ideas) - S5

- Communicating - S6 information and ideas $\quad$ - S7

- Responding (in role) to news of forest clearing

- Inferring, speculating in role/out of role (meanings, consequences)

- Stating own opinions on the issue - in role and out of role

- Finding additional information

\section{ESD Attitudes/Values}

- Willingness to participate in general

- Sympathy/empathy with characters showing concern

- Making ethical/value judgements - about the situation faced by the forest people and about the issue of deforestation 
of the stated learning outcomes in knowledge, skills and attitudes were coded (see Table 1) and these codes were applied to the transcriptions, as well as to the children's written responses. Using this 'top-down' strategy, a range of evidence about learning was gathered. The next stage sought to relate the learning that had occurred in environmental education to the experiences that the children had had in the drama lessons. It asked, which techniques and activities might have been useful in promoting learning? Here, each of the techniques and dramatic conventions employed would be set against the proposed learning and then the actual learning that had been identified in the first stage of the analysis. The analysis process in this case would be mainly 'bottom-up', with themes, categories and issues emerging from the data. The analysis of the 'Rainforest Drama', here, is an example of the synthesis of these two analytical processes.

Finally, it would be necessary to examine the evidence from the analysis of the data in the light of theories about how learning occurs and what makes learning successful. Analysis of the videotapes of lessons would also be used here. From these might emerge a theory about what it is about drama that makes it a useful learning tool. The first, tentative, stages of this process are discussed at the end of this article.

\section{An example of the analysis process - children's written evaluations}

To exemplify the analysis process I have included an abridged version of the analysis of one of the sets of data, the children's written evaluations of the lessons. At the end of the series of lessons, each child completed an evaluation form. For each set of evaluations, the responses to each question were counted, grouped into a number of categories, summarised and collated onto one sheet. In that way, the range of responses could be examined more easily (see Table 2). Data from 'The Rainforest' lessons have been selected to provide continuity with the aims and learning outcomes shown in Table 1 .

It must be recognised, however, that the numbers in the table tell only part of the 'story' of the data. The counting of the responses reveals trends and enables the researcher to gain a broad understanding of the children's opinions, but it is in the quality of the children's individual responses, that is, the qualitative data, that the real telling detail can be found. In the commentary of the data, which I have linked to the proposed learning, I discuss the general trends but also try to give a sense of the nature of the responses.

\section{Discussion of responses}

Questions 1, 2 and 3 were focused on finding out which parts of the drama were most memorable and therefore, perhaps, had the greatest influence on the children's learning. In answer to Questions 1 and 2, when they were asked about the parts they remembered best and which part was their favourite, the children mainly sited the 
Table 2. The collated responses of Classes A and B evaluations of 'The Rainforest' lessons

\begin{tabular}{|c|c|c|c|c|c|}
\hline Class A (23 pupils) & \multicolumn{2}{|r|}{ Class B (27 pupils) } & \multicolumn{3}{|c|}{ Learning links/codes } \\
\hline \multicolumn{6}{|c|}{ 1. In the drama work about 'The Rainforest', list three bits in the drama that you remember best. } \\
\hline Pretending to be the Beasts & 7 & Deciding to go or stay & 19 & Aim 1 & CK1 \\
\hline The woman with the baby & 6 & Talking to the worker & 10 & & CK2 \\
\hline Hunting for animals & 1 & Pretending to be the beasts & 6 & Aim 2 & S1 \\
\hline Talking to the worker & 5 & The woman with the baby & 5 & & S2 \\
\hline $\begin{array}{l}\text { Being a bodyguard/chief (the 'guards' } \\
\text { \& 'chief') }\end{array}$ & 3 & Hunting for animals & 9 & Aim 3 & S3 \\
\hline The messenger/stranger & 4 & The messenger/stranger & 3 & & $\mathrm{~S} 4$ \\
\hline Making/Living in the village & 4 & The still image & 2 & LO 2 & S5 \\
\hline Having meetings to plan & 6 & Being the bodyguard & 2 & & S6 \\
\hline Deciding to stay or go & 4 & The lady with the truck & 3 & LO 3 & A1 \\
\hline Other & 2 & Other & 4 & & $\mathrm{~A} 2$ \\
\hline \multicolumn{6}{|c|}{ 2. What was your favourite part of the drama work? } \\
\hline Speaking to the worker & 2 & Speaking to the worker & 2 & & \\
\hline Person from the other village & 4 & Still images/hearing thoughts & 4 & Aim 2 & $\mathrm{~S} 2$ \\
\hline Hunting & 1 & When we had to decide & 8 & & $\mathrm{~S} 4$ \\
\hline Morning in the forest/village & 2 & Being the Beasts & 2 & LO1 & CK1 \\
\hline Talking in the market & 2 & Being the guard & 2 & & CK2 \\
\hline Going to see the machines & 2 & Hunting & 1 & LO3 & S1 \\
\hline When the man was dying & 1 & Living in the forest & 1 & & S6 \\
\hline All of it & 2 & Choosing who you could be & 2 & & \\
\hline Other & 4 & Other & 3 & & \\
\hline \multicolumn{6}{|l|}{ 3. Why did you like this? } \\
\hline Had to pretend/role play & 3 & Lifelike & 2 & & \\
\hline Lots of action/exciting & 4 & Exciting & 4 & Aim 2 & S1 \\
\hline Talk to other people & 2 & $\begin{array}{l}\text { Hear what people were } \\
\text { thinking }\end{array}$ & 2 & & \\
\hline
\end{tabular}


[Table 2. (Continued)]

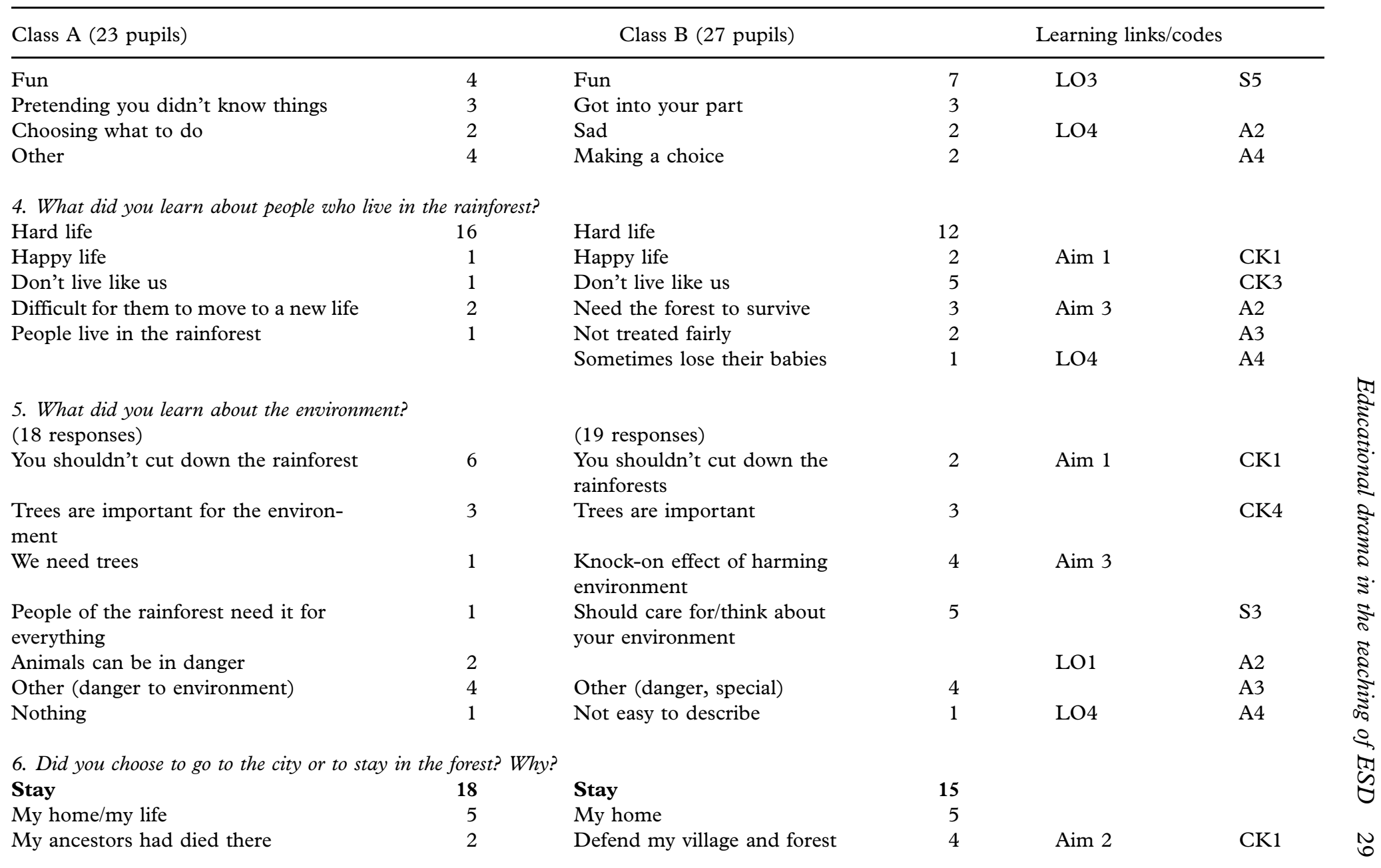


[Table 2. (Continued)]

\begin{tabular}{lllrl}
\hline Class A (23 pupils) & \multicolumn{1}{c}{ Class B (27 pupils) } & Learning links/codes \\
\hline With my own people/family & 2 & With my own people & 2 & Sim 3 \\
Wouldn't know what to do in town & 2 & Live my own life & 3 & S5 \\
Bad life in the city & 1 & I was the chief & 1 & AO4 \\
I/we had rights & 2 & Go & $\mathbf{1 0}$ & A3 \\
No response & 4 & Better life & 5 & A4 \\
Go & $\mathbf{2}$ & Job & 2 & \\
Better life & 2 & Too scared to stay & 1 &
\end{tabular}

7. Do you have any other comments?

Fun; brilliant; 'as if' is good drama; I want to do it again; I didn't know drama could be so interesting; thank you 
key dramatic encounters and action in the lessons - 'it was fun/good fun/interesting'. A number of responses cited the whole 'acting' and 'pretending' process as being memorable. However, almost all of the responses refer to specific incidents or scenes of dramatic tension - times in the drama when the children were being the characters 'inside' the story. They were caught up in reacting and responding in role as they engaged with the problems or dilemmas faced by the villagers.

Some examples of the children's responses to Questions 1, 2 and 3, listing which parts they remembered best, included:

- arguing with my family to see who was going or staying. You had to really think about it;

- when the lady was telling us that it was better to go to the town. You knew she wasn't really on your side;

- at the end when some people left our forest. It was very sad;

- when we were being the monsters because it was fun and you had to try to be realistic;

- because you really had to pretend to be the person.

Questions 4 and 5 were designed to gain specific information about what the children believed they had learned through the drama. In answer to Question 4, the children expressed sympathy for and empathy with people who live in the rainforests and who might suffer a similar plight to those in the drama. Many of the children focused on the idea that the people of the rainforest had 'a hard life'. There is some evidence of an awareness of the human rights issue of land ownership and dispossession. They said that it must be difficult to be often worried about whether your home/land would be safe. Most said that they would not want to be in that situation. Many answers were thoughtful and expressed ideas clearly. Some examples of the responses were:

- they should be angry at people cutting down trees;

- they are like a big community and are happy but they have a hard life;

- that it would be very hard for them just to move to towns;

- it's not fair to drive them out of their homes. We wouldn't like it.

The answers to Question 5 focused on what the children thought that they had learned about the environment. There were statements indicating that the children were aware of the environmental impact of deforestation and about the need to conserve what is left of the world's rainforests. They were also aware of the impact that one action can have on another: interdependence. 'If one part of the world is hurt the other parts will be effected (sic).' Other examples of the responses were:

- you should care for/protect your environment;

- to look after the environment because it isn't just you that lives in the world;

- I didn't learn anything new but it made me think about it more. 
Question 6 asked the children if they chose to remain in the forest or to go to the city. The striking thing about all of the responses is the use of the first person possessive pronouns in the responses. Many who chose to stay wrote that the village/forest 'was my home', 'my life'. Those who chose to go cited to 'have a better life' as the main reason for going. However, in later discussion they said that their character thought that life would be better, but that they themselves did not.

The final question, Question 7, asks for any other comments. Although not every child responded, the responses given were very positive, with the children stating that they thought that the drama was fun, that they liked working in a team and that they hoped that they would be able to take part in further drama work.

\section{Learning in ESD_knowledge, skills and attitudes}

In the evaluations, the children's responses provide evidence of learning relating to Aims 1, 2 and 3 and Learning Outcomes 1, 3 and 4.

In their responses, the children demonstrated that they were aware of the effects of deforestation on the lives of the people of the rainforests and of the social and economic impact of the continuing clearing of the world's forests. They were able to site a number of possible reactions, both physical and emotional that these people might experience. It is clear that the drama had an impact on the children's understanding of the impact of deforestation and dispossession in terms of human rights and social justice. This was more evident in later interviews based on the evaluation forms. It must be recognised that the drama had not been planned specifically to teach the children to become aware of the environmental facts surrounding deforestation such as global warming, depletion of the earth's resources. However, in providing a meaningful context, the children's overall interest in and learning about the topic may have been enhanced.

There is evidence in the children's responses of their awareness of their employment of a wide number of skills. There is evidence of their ability not only to devise and sustain their own chosen role within the community but also to work collaboratively (both in and out of role) to develop and extend the fictional context. Responses were often framed in the first person plural: 'we worked together'; 'we were having to decide/choose/pretend'. The nature of the drama activities afforded the children opportunities to develop essential skills in co-operating, collaborating, communicating their thoughts and ideas, stating their own opinions and listening to the opinions of others. There is also evidence of the use of higher-order skills: synthesis of ideas and information. They were able to infer and speculate about meanings and intentions and they could make important and difficult decisions by weighing up options.

There is no doubt that the children were very involved with their characters and that there was a high level of engagement in the story of 'The Rainforest'. The 
children's responses reveal sympathy for people whose lives are affected by deforestation and displacement and also a degree of empathy. For example, statements such as 'I stayed because the rainforest is my home' and 'this was the land of my ancestors and I had to protect it' seem to suggest that the children had, at some level, experienced some of the feelings of the characters.

An attitude that was more implicitly suggested than explicitly stated in the responses was that of the children's willingness to take part in the activities. Their responses reveal that they not only took part willingly but that they found the drama to be 'exciting', 'interesting' and 'fun', and that 'it was good hearing everybody's thoughts'. A positive learning environment might be more likely to generate interest and enthusiasm for the subject being taughthere, ESD.

\section{Drama and learning}

In this section, two key episodes in the drama are discussed in terms of the drama conventions to which they are related. This discussion may serve to illustrate the theoretical perspective offered in the final sections of this article. Also, because they contain descriptions of aspects of the drama work, they may help to give the reader a 'flavour' of how the lessons were implemented. Two scenes, most often cited as memorable in the children's evaluations and interviews, are discussed. I have selected these as they illustrate two different aspects of the drama work. Dramatic conventions are given in bold.

\section{Scene 1-The coming of the beasts}

Quite a number of children cited this scene as memorable. This activity allowed the children to create a sound, movement and mime piece which depicted the scene of the forest clearing work. The purpose was to allow the children to experience the power and relentlessness of modern deforestation through kinaesthetic and dynamic engagement. 'The Beasts', here, was a metaphor for the apparent lack of concern for sustainability issues demonstrated by the huge forest clearing operations. The creative piece was an aesthetic interpretation rather than a naturalistic representation. Groups of four or five collaborated to make a 'beast', putting together chopping, cutting, sawing, etc. movements with appropriate sound effects. The teacher narrated the story as the children group by group, then ensemble, recreated the scene. At several points the action was frozen (freeze frame) so that the children could consider the whole scene. The children took this part of the drama very seriously and many said that they could really imagine the forest scene clearly. They put a lot of effort into making their chosen machines as accurate as possible, consulting photographs and discussing specific technical details. The drama observer remarked on the children's engagement and creativity of their responses. 


\section{Scene 2-Leaving the village}

There was a marked difference in one set of responses. More than half of Class B (19 children) said that they had remembered the part when the community were leaving the forest. Only four of the children in Class A cited this as memorable. This may be linked to the fact that in Class A, all but two 'villagers' chose to stay in the forest and take their chances with the Deforestation Company. The end of the drama was serious and quiet, with the children speaking their thoughts (thought tracking) and the 'company representative' (teacher in role) saying goodbye, leaving them to their fate. It was quite a different scene with Class B. With each class, as the 'company representative', I spoke to the villagers and gave them the choice of whether to come with me 'in my truck' or stay and fight - a fight, I pointed out, that they could not win. (The representative, in an earlier scene when they first met her, had pointed out that she too had lived in the forest before going to the city to 'be educated' but had lost the trust of the villagers when she became increasingly defensive of the company.) Each class responded in the same way, with hostility and growing disrespect (many would not sit down when I asked them to, they pointed 'spears' at me, they shouted at me to leave, etc.). I stood up with my clipboard and asked them to line up and sign to show that they would go with me (on a piece of paper that I read to them as 'The company promises to take good care of the people who go with the Representative'. They could see clearly that it read, 'The Company takes no responsibility for the people who go with the Representative'). This was an example of dramatic irony - the pupils could read the paper but some of the 'villagers' could not. I was astonished that a number of the children in Class B came forward to sign, as they had given no indication that they would do this. A quote from my research diary gives an indication of my response at the time.

When one then another came up to sign I was really surprised. The fact that the others were begging them not to, were crying, were calling them names, etc. was having no effect on some and swaying others. I could see, beyond the clipboard, that all this was going on but I could do nothing really to control it or be part of it. That was their story, standing with the clipboard was mine. I felt that I was inside the story with the children as well as being the teacher. Being engaged and involved means that, in a way, you are all working as equals, in real collaboration. You're relying on them as much as they are on you.

When all had signed/not signed I thanked everyone very formally and asked those leaving to line up at one side 'near the truck' and the rest to stand on the 'village boundary' (ritual). The mood was electric. Some were still asking the others to come back, but mainly, they were very quiet. We made a still image (still image) and did a thought track (thought tracking) around the room. This was a real eye-opener. Reece, who was usually very quiet, said 'They are all traitors'. Others surprised me too. Kirsty said that she didn't want to go but that she felt that she had no choice. Janice said that she wanted a better life. In the feedback session at the end, I asked the children who chose to go if they really thought that the people would have a better life in the town. They said that they didn't believe this (they might be homeless or be unhappy as they would have no skills) but that their characters did. 
This was a powerful and moving end to the drama and it seemed to have an effect on many of the participants - including the teacher.

\section{Summary of the key areas of effective learning}

McNaughton (2004) describes the first stages of this research, concentrating on 'The Dump' drama and suggests four areas of learning in and for ESD in which drama may be particularly useful (sympathy/empathy; skills development; values; context for learning). This section takes that discussion further.

\section{Sympathy and empathy}

As in 'The Dump' drama, in 'The Rainforest' drama, the children were very involved with the imaginary context and seemed to identify closely with the characters that they had built and developed. They seemed immersed in their roles, not just as individuals but in the way they reacted to and responded to each other in role-offering advice and comfort, showing concern for other members of their 'family' and community. Out of drama, the reflective discussion often centred on concern for the villagers - were they getting enough food, what would happen if the hunters got hurt, how would the children cope with the news of the destruction of the forest? This was particularly evident in the evaluations and discussion linked to the villagers' decision about whether to go or stay. They were very aware of the dilemma and expressed worry and concern for the villagers, whatever their decision. 'They won't have an easy life in the city, but they can't stay in the forest.'

\section{Exploring values and attitudes}

The Global Dimension in the Curriculum (LT Scotland, 2001) states that learners should 'gain experience of, develop and practice values and dispositions that are crucial to a just and democratic society and a sustainable world'. The drama, perhaps, helped the children to imagine the experience vividly. Beyond sympathy and empathy, the fiction of the drama provided the children with an immediate and meaningful context in which to explore some of the very real issues affecting many millions of people across the world such as poverty, homelessness and disempowerment. The evidence from their responses strongly suggests children were able to recognise and discuss a range of sustainable development ideas and values linked to human rights and environmental responsibilities. Neelands (2004) draws a parallel between 'the public and social theatre of active democracy' and drama, in that they both hold 'the same potential for us to listen to and be moved by stories and claims of others who hold different values, purposes and traditions from our own' (p. 35). The drama scenarios provided the children with opportunities to explore a range of values other than their own and to begin to explore and consider their own values and responses to some of the issues linked to deforestation. 


\section{Skills for effective learning}

'Drama allows children to rehearse and develop the skills they will need for active citizenship in a safe and non-threatening situation' (McNaughton, 2004). There is evidence from 'The Rainforest' drama of the used of a wide range of high-level skills. Effective communication and use of language in drama work go beyond the nominal and descriptive and require the application of higher order skills such as synthesising ideas in order to question, explain, reason, justify, and form and express opinions. In addition, social skills such as working collaboratively, sharing, listening and responding, compromising and reaching decisions are necessary both for successful interaction in drama and for being active, effective members of the local and global community.

\section{Engagement with learning}

In A Curriculum for Excellence (Scottish Office Curriculum Review Group, 2004) the Curriculum Review Group advises that, in a new curriculum, 'Young people should find their learning challenging, engaging and motivating' (p. 12). There is substantial evidence that, during the drama, the children were fully engaged and actively involved in the learning experience. Within the unfolding story of the drama, they were faced with a number of challenging, unfamiliar situations calling for carefully considered responses. This was at the same time, exciting and motivating. The Review Group also advises that pupils should have opportunities to 'develop and demonstrate their creativity' and to 'sustain their effort'. The drama offered opportunities for both. Because of the wide range of theatre-based conventions employed, responses, both vocal and physical, were often creative. The pupils were required to consciously sustain their roles within the drama and, in post-drama discussion, it was evident that they were very aware of this. 'You had to keep being your character or the drama wouldn't work.'

\section{Positive classroom climate}

The observers of the drama work noted that during the course of the lessons, there were very few instances of disruption and, although there were a few short reminders of rules for behaviour (sometimes from the teacher in role, 'If we don't all work together here, we'll never find a way to defeat the beasts') at no time did any pupil have to be excluded from a lesson. In the evaluations, a number of pupils commented that they 'got on well' within the groups and that 'everybody worked together well'. Massey (2003) describes a positive classroom climate as one in which there is 'a caring atmosphere and respect for self and others' (p. 5). The 'contract' of behaviour and attitude that is negotiated with the participants before each drama lesson allows discussion of boundaries and provides a more collegiate model of discipline. A degree of self-control and 'working for the common good' is often the outcome. 


\section{Providing a context for learning}

The story developed though the drama provided a meaningful context and a real purpose for the children's classroom work on their rainforest topic. The children, using books and Internet resources, prepared booklets, posters and reports, describing the problems caused by deforestation and advising of steps people could take to help to reduce the destruction, for example avoiding buying tropical hardwood from non-sustainable sources and avoiding eating hamburgers from certain sources. Some of this work was carried out at home in their own time. The drama may have stimulated the children to engage with their learning, to make a personal reconstruction of knowledge and thus, perhaps, to come to a fuller and more meaningful understanding.

\section{Drama and Education for Sustainable Development - pedagogical links}

There was substantial evidence that the drama had addressed a range of the stated learning outcomes in Education for Sustainable Development. A number of reasons for this begin to emerge from the data.

\section{Democratic teaching}

In writing about the teaching of and for global citizenship, Massey (2003) described a style of 'democratic teaching'. The characteristics of a democratic classroom are defined as those which offer learners opportunities to: participate in decisions; think freely, express their views and discuss various perspectives; experience a positive classroom climate; and learn how to be active contributors to class, community and society. The context of a drama lesson may help the participants to look explicitly at ways of living and may explore issues. However, because of the nature of teaching in drama, the drama classroom may often model, implicitly, a well-balanced, democratic society. Freedom of expression is bound up with rules and responsibilities in terms of behaviours and values - for example, sharing, collaborating, being tolerant and working towards a common goal. Massey's descriptions match the values fundamental to good drama teaching. Central to this is the relationship between the teacher and the pupils during the drama lesson. Additionally, within the drama, when the teacher is working in role alongside the pupils, there is the potential for the development of relationships outwith the normal teacher-pupil repertoire. The teacher's role may often have equal or lower status than the pupils' characters. The teacher's character may be vulnerable or hostile. The pupils may choose to accept or reject the ideas or requests made to them by the teacher when in role. It is the dynamic resulting from this change of status that allows the pupils real freedom of expression and real opportunities for thinking and decision-making. 


\section{Metacognition and the construction of learning}

Livingston (1997) states that, 'Knowledge is considered to be metacognitive if it is actively used in a strategic manner to ensure that a goal is met' (Internet article). In the drama, the pupils displayed a high level of awareness of their own knowledge and understanding. For example, in role as villagers, they were constantly monitoring and adapting their in-role behaviour, using their knowledge in order to interpret the villagers' actions and responses. They were engaged in what Bolton (1984) terms 'As if ...' behaviour. Each member of the group engaged in a willing suspension of disbelief in order to make the drama 'work'. This striving to inhabit both the real world and the imagined world, and being aware of both, demonstrates metacognition. In reflection out of role, they were able to identify gaps in their knowledge (What might the villagers eat or wear? What would logging machinery look like? How many trees can be cut in a day?). The pupils then sought to fill these gaps through research and they were able to bring a wider knowledge-base to subsequent parts of the drama work. The implications for learning, here, would suggest that the drama allowed the pupils to be more aware of their own learning development and needs and provided real contexts leading to more effective, meaningful learning in EDS.

Barnes (1992) states that 'each of us can only learn by making sense of what happens to us through actively constructing a world for ourselves' (p. 123). In drama, a constructivist approach is employed both in the in-role, active, narrative mode and in the out of role, discursive, reflective mode. In the first mode, the skill of the teacher is in leading the children through the story while at the same time taking the lead from them: being responsive and reactive rather than imposing her own ideas and constructs. In the second mode it is the teacher's role to help the children to sort out and articulate their ideas and to reflect on what the drama (the actions, the words) might have meant. It could be claimed that drama allowed the pupils to construct and develop their own meanings. The drama led them to ask questions the answers to which helped to develop their knowledge and understanding, opinions and values about the depletion of the rainforest and its consequences.

\section{The art-form of drama}

It is important, here, to consider how drama itself, not only as a learning medium but also as a unique art-form in its own right, may have contributed to the pupils learning in ESD. When drama is undertaken as part of a wider learning process there is often no end performance to an external audience. Yet many of the conventions of theatre contribute to the repertoire of the classroom drama. Dramatic conventions such as role-building (Who are you? What do you do/know?) and defining space (This is the Rainforest) help to draw the children into the fictional context. The introduction of problems or dilemmas (What can we do? What will we chose?) creates moments of dramatic tension. Improvisations, often with teacher in role, help to drive the narrative: to provide information or to examine alternatives or to move the story on. However, the 'art' of drama lies not in a realistic depiction of the story but in the 
representational nature of many dramatic conventions. Neelands (1990) terms this the 'Poetic Action' of drama (p. 34). Nicholson (2000) states that 'unlike many traditional education practices which are dominated by the written word, drama is a "multi modal" art form, and necessarily requires students to use visual images, movement and sound as well as words' (p. 4). In 'The Rainforest' drama, the group mime/movement work (with sound effects) of 'The Beasts eating the forest' was based on research about logging equipment but ultimately it was an interpretive response depicting concepts such as strangeness, power and destruction. Near the start of the drama, each community 'family' created a still image of the beginning of the day - going about their normal daily 'business'. At the end of the session, each family again created a still image, this time focusing on their feelings and responses to the news of 'The Beasts'. There was a marked difference between this and the first image both in the quality of the final images and in the level of commitment that the pupils brought to the task. The physical representation allowed the pupils to reflect on the unfolding story in a non-verbal, abstract way. The use of the art-form allowed the pupils to examine and interpret the emotions and reactions of the villagers-what it meant for them to be facing a threat to their way of life - at a level not often possible in discussion-based activities.

\section{Story as a way of learning}

Egan (1992) states that it is the development of the 'narrative capacities of the mind' (p. 62) which are so central to our general capacity to make meaning out of our experiences. Further to this, Winter (1988) asserts that, 'We do not store experience as a date, like a computer: we story it' (p. 246). All cultures engage in story as a way of teaching, passing on information and enabling the understanding of important events and issues. However, in drama, the pupils are not the passive recipients of the story but are actively involved in the unfolding proceedings, shaping events and facing the challenges and dilemmas of the characters. Winston (2000) uses the phrase 'the moral power of the enacted narrative' (p. 94) when discussing drama's ability to help pupils to engage in key themes underpinning moral education. Many of these, for example, concern for others, respect and social justice, are also the central themes of ESD. Within the imagined context of the drama, often as a result of the challenges set by the teacher while in role, ideas and values may be considered and explored.

Huckle (2002) suggests that modern primary education should be about helping children to gain the 'enlightenment' they will need to live in a rapidly changing world. He states that, 'above all, it should be an education linked to realistic narratives of hope: stories of communities finding ... routes to sustainability' (p. 5). Engaging the children in the story behind the environmental facts may put the ideas in context and give them a 'particular' on which to focus. This can then be extended out to general facts and understandings. McNaughton (2004) suggests that the sustainability-based story underpinning the drama may also be a metaphor for real life. The drama about 
people in the rainforest being evicted, for example, is a story in itself, but it may also be a metaphor for the displacement and disaffection felt by the many thousands of people worldwide who, under a variety of circumstances, suffer persecution or are made homeless every day. The art-form allows us to go beyond the literal to explore the connotative meanings created through the verbal and physical engagement with ideas. The power of the drama is not that it teaches facts about sustainability but that the underlying issues are explored in a more holistic multi-faceted way. Universal concepts such as oppression, dispossession and the misuse of natural and human resources lie at the heart of educational drama in Education for Sustainable Development.

\section{Notes on contributor}

Marie Jeanne McNaughton is a Senior Lecturer in the Department of Childhood and Primary Studies at the University of Strathclyde, Glasgow. She is the Environmental Studies co-ordinator on the B.Ed. (Hons) course. She is involved in a number of initiatives for the promotion of Education for Sustainable Development in Scottish schools. She is editor of Reflections newsletter and Drama, the journal of National Drama.

\section{References}

Baldwin, P. (2004) With drama in mind (Stafford, Network Educational Press Ltd).

Barnes, D. (1992) The role of talk in learning, in: K. Norman (Ed.) Thinking voices: the work of the National Oracy Project (London, Hodder and Stoughton Educational).

Bell, J. (1993) Doing your research project (Buckingham, Open University Press).

Bolton, G. (1984) Drama as education - an argument for placing drama at the centre of the curriculum (London, Longman).

Edmund, K., James, H., Wilde, A., et al. (2001) Woven lives - a creative approach to citizenship and sustainable development for 7-11 year olds (Nottingham, MUNDI, Centre for Development Education).

Egan, K. (1992) Imagination in teaching and learning age 8-15 (London, Routledge).

Hitchcock, G. \& Hughes, D. (1995) Research and the teacher-a qualitative introduction to schoolbased research (London, Routledge).

Huckle, J. (2002) Educating for sustainability (Birmingham, National Primary Trust).

Laing, M. \& McNaughton, M. J. (2001) Environmental education should take children further, Scottish Educational Review, 32(2), 168-179.

LT Scotland (2001) The global dimension in the curriculum (Dundee, Learning and Teaching Scotland).

LT Scotland (2002) Education for citizenship in Scotland: a paper for discussion and development (Dundee, Learning and Teaching Scotland).

Livingston, J. (1997) Metacognition - an overview, web-page for CEP 564 Cognitive Psychology, University of Chicago, available at http://www.gse.buffalo.edu/fas/shuell/cep564/ Metacog.htm (accessed 8 June 2005).

Massey, I. (2003) Rights respect and responsibilities: children's rights to education in Hampshire, Hampshire County Council website, available at http://www3.hants.gov.uk/education/ childrensrights/rrrthecase.htm (accessed 12 June 2005). 
McNaughton, M. J. (2004) Educational drama in the teaching of education for sustainability, Environmental Education Research, 10(2), 139-155.

Neelands, J. (1990) Structuring drama work (Cambridge, Cambridge University Press).

Neelands, J. (1992) Learning through imagined experience (London, Hodder \& Stoughton).

Neelands, J. (2004) The idea of IDEA, Drama fournal, 12(1), 31-39.

Nicholson, H. (Ed.) (2000) Teaching drama 11-18 (London, Continuum).

O’Neill, C. (1995) Drama worlds - a framework for process drama (Portsmouth, NH, Heinemann).

Scottish Office Curriculum Review Group (2004) A curriculum for excellence (Edinburgh, Scottish Office).

SOED (1991) Curriculum and assessment in Scotland national guidelines, expressive arts 5-14 (Scotland, HMSO).

Stenhouse, L. (1975) An introduction to curriculum research and development (Oxford, Heinemann Educational Books Ltd).

Sustainable Development Education Liaison Group (2004) Sustainable development education in England, Wales, Northern Ireland and Scotland (Dundee, Learning and Teaching Scotland).

UNESCO (2005) The decade of education for sustainable development, available at http://

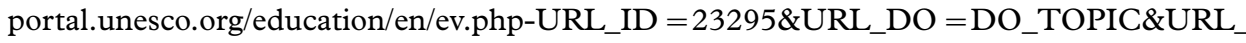
SECTION $=201 . \mathrm{html}$ (accessed 4 June 2005).

Wagner, B. J. (1976) Dorothy Heathcote, drama as a learning medium (London, Hutchinson).

Winston, J. (2000) Drama, literacy and moral education (London, David Fulton Publishers, Ltd).

Winter, R. (1988) Fictional-critical writing, in: J. Nias \& S. Smith (Eds) The enquiring teacher (London, Falmer Press). 